\title{
Mamey (Mammea americana L.) in Martinique Island: an inheritance to be developed
}

\author{
Laurent GervaIS, Christian LAVIGNE*
}

Cirad, UPR 77, PRAM, Petit Morne, BP 214, 97285 Le Lamentin Cedex 2, Martinique, France lavigne@cirad.fr
* Correspondence and reprints

Received 17 October 2006 Accepted 7 February 2007

Fruits, 2007, vol. 62, p. 237-246 (C) 2007 Cirad/EDP Sciences All rights reserved DOI: 10.1051/fruits:2007019 www.fruits-journal.org RESUMEN ESPAÑOL, p. 246

\author{
Mamey (Mammea americana L.) in Martinique: an inheritance to be \\ developed.
}

Abstract - Introduction. Mamey (Mammea americana L. Clusiaceae) was present in Martinique before the Spanish colonization. Its distribution area includes tropical America and the Caribbean. A significant phenotypical diversity is observed on the island, with fruits of very uneven quality as well as various agronomic, pomological and biochemical characteristics. The aim of our work was to localize, identify and characterize trees considered of superior quality. Materials and methods. A survey carried out between April and September 2005 allowed the selection of 10 trees renowned by the people as bearing high-quality fruits. These fruits present a small number of seeds and nonadhesive pulp, and develop a sweet taste as well as a strong flavor. During the year 2006, pomological description and biochemical analysis (total soluble solids and total titrable acidity) were carried out on the fruits. Results and discussion. The biometric and biochemical characteristics measured were generally better than those cited in the literature. Some accessions stand out and present great assets for their promotion for the fresh market as well as for processing. Moreover, some tendencies emerged from the variability observed for a few characters: thus, the variability of the biochemical characteristics measured within one accession, as well as between accessions originating from the same land, is low. It is null for the seed adhesion to the pulp for fruits belonging to the same accession. Conclusion and perspectives. Our work is one of the first relating to identification and characterization of phenotypical diversity of the M. americana L. species, especially in Martinique Island. Our results are likely to promote the development of a diversification network. Some highlighted trends suggest new research to be able to distinguish the role of the environmental versus genetic components in the performance of the phenotypes observed.

Caribbean / Martinique / Mammea americana / fruits / genetic variation / diversification / selection criteria

\section{L'abricot des Antilles (Mammea americana L.) à la Martinique : un patrimoine à valoriser.}

Résumé - Introduction. L'abricot des Antilles (Mammea americana L., Clusiaceae) était présent à la Martinique avant la colonisation espagnole. Son aire de répartition englobe l'Amérique tropicale et la zone caraibe. Une importante diversité phénotypique est observée sur l'île, avec des fruits de qualité très inégale et des caractéristiques agronomiques, pomologiques et biochimiques bien différenciées. Notre étude a porté sur l'identification d'individus réputés comme supérieurs et la caractérisation phénotypique de leurs fruits. Matériel et méthodes. Une prospection réalisée entre avril et septembre 2005 a permis la collecte de fruits de 10 arbres remarqués par la population comme donnant une production de bonne qualité : présence dans les fruits de graines peu nombreuses et non adhérentes à la pulpe, ainsi que saveur bien sucrée et arôme prononcé de la pulpe. Au cours de la période de production de 2006, des analyses biométrique et biochimique complémentaires (extrait sec soluble et acidité libre totale) ont été réalisées sur les fruits à la récolte. Résultats et discussion. Les caractéristiques biométriques et biochimiques mesurées lors de nos analyses ont été le plus souvent supérieures à celles citées dans la bibliographie. Certaines accessions de Martinique se sont distinguées et présentent des atouts importants pour leur diffusion en frais et pour une transformation de qualité. D'autre part, certaines tendances se dégagent par rapport à la variabilité observée de certains caractères. Ainsi, la variabilité des caractéristiques biochimiques mesurées au sein d'une même accession et entre accessions d'un même terroir est faible. Elle est nulle lorsqu'il s'agit de l'adhérence des graines à la pulpe de fruits appartenant à une même accession. Conclusion et perspectives. L'étude présentée est l'une des premières portant sur l'identification et la caractérisation de la diversité phénotypique présente chez l'espèce $M$. americana L. en général et plus particulièrement sur l'île de la Martinique. Les résultats obtenus sont encourageants pour le développement d'une filière de diversification. Certaines tendances mises en évidence dégagent de nouvelles perspectives de recherches quant au rôle des composantes environnementales et génétiques dans la performance des phénotypes observés.

Caraibe / Martinique / Mammea americana / fruits / variation génétique / diversification / critère de sélection 


\section{Introduction}

Since the Sixties, the agricultural research center for developing countries (CIRAD) has continued a program of diversification of the fruit-bearing production in the West Indies, in order to reduce the economic and agronomic risks related to an agriculture based on only the pivotal crops (banana, sugar canes and pineapple). The present few productions of diversification (citrus fruits, mango and guava) are intended primarily for the local market. Consequently, research efforts today relate to the valorization of the local biodiversity and, in particular, to the indigenous species of the Caribbean basin, particularly threatened because of their insular environment: land pressure, excessive deforestation, appearance of invasive plants, and pollution of agricultural, industrial or domestic origin. In this context, we were interested in the diversity of the mamey (Mammea americana L.), which belongs to the fruit-bearing inheritance of Martinique inhabitants. Our study is integrated into a total program set up in the West Indies to improve the availability of fruits of quality, and to develop a local inheritance which is still too little known.

The mamey presents real nutritive and gustatory properties, as well as commercial potential at a local level, and even at an export level; however, little work has been undertaken on the phenotypical characterization of its diversity. However, a recent American study identified and collected clones of high quality while being based on a prospecting similar to that which we adopted, but it was carried out over a geographical area broader than ours, including Central America, the Hawaiian islands and the Dominican Republic [1]. In addition, former studies have revealed some general knowledge of $M$. americana, that we synthesize as a precondition to the presentation of our work

The species $M$. americana belongs to the family of Clusiaceae. It originates from the West-Indian Arc and the North of South America [2,3] and is found in the whole of the Martinique territory, especially in the zones with strong rainfall. This indigenous species was introduced into Martinique by the first explorers [4]. It is a tree which can measure up to $25 \mathrm{~m}$ in height. It presents a slowed-down growth on sandy grounds [3] such as eroded and compacted grounds [5]. M. americana can be observed up to $1600 \mathrm{~m}$ of altitude [5]. The species is commonly planted in Creole gardens and near the roads of Martinique Island. It is very appreciated by the local populations for its fruit or its wood; it is also used as an alignment tree. M. americana also has many medicinal virtues: pest-destroying treatment of the skin (Venezuela), use against fevers (Brazil) or to complement quinine (Brazil), assistance with the extraction of foreign bodies accidentally entered into the flesh, washing and cicatrization of wounds (the Antilles) [3, 6] and insect-repellant properties $[3,7]$.

The fruit is a berry [3] which on average weighs (500 to 2000) $\mathrm{g}$ [5]. The exocarp is of clear beige to brown dark color, and of variable thickness and verrucosity. The mesocarp is reduced to a whitish film subjacent, more or less adherent to the exocarp and slightly bitter. The endocarp, the edible part of the fruit, is of yellow to orange color, relatively firm, and contains one to four seeds, adherent or not to the pulp. It is possible to observe vestiges of aborted seeds in these fruits [1]. The seeds have an average weight of $70 \mathrm{~g}[1,5]$. According to recent studies on the biology of its reproduction, the species M. americana presents a "cryptic" androdioecy, i.e., there exist individuals with male flowers and individuals with functionally female hermaphrodite flowers [8].

The propagation of mamey is primarily carried out by sowing, which allows the maintenance of a great genetic variability. In Martinique Island, the principal crop period extends from April to September, but certain trees produce fruits at other periods of the year. The fruits are consumed fresh or artisanally or industrially transformed into juice and jams. The flowers were formerly distilled for making of an aromatized liquor called "Creole water" [3, 4, 9]. Only three bibliographical references deal with fruit composition and storage: fruits are climacteric [10], their storage is the best at $(15 \pm$ 2) ${ }^{\circ} \mathrm{C}[11]$ and their provitamin A content is high [12]. 
Table I.

Name, localization, type of soil, altitude and coordinates of ten trees of Mammea americana, selected for the quality of their fruits in Martinique Island.

\begin{tabular}{|c|c|c|c|c|}
\hline Accession & Commune & Soil type ${ }^{1}$ & $\begin{array}{l}\text { Altitude } \\
(\mathrm{m})\end{array}$ & Coordinates \\
\hline Belleville & Le-prêcheur & Brown soil rusts with halloysite & 276 & $14^{\circ} 49^{\prime} 16.8^{\prime \prime} \mathrm{N}, 61^{\circ} 13^{\prime} 05.9^{\prime \prime} \mathrm{W}$ \\
\hline Charité & Trinité & Ferrisols & 85 & $14^{\circ} 44^{\prime} 29.8^{\prime \prime} \mathrm{N}, 60^{\circ} 58^{\prime} 26.8^{\prime \prime} \mathrm{W}$ \\
\hline Choisy & Saint-Joseph & Brown soil rusts with halloysite & 101 & $14^{\circ} 39^{\prime} 42.7^{\prime \prime} \mathrm{N}, 61^{\circ} 00^{\prime} 50.9^{\prime \prime} \mathrm{W}$ \\
\hline Coco & Saint-Esprit & Vertisols & 245 & $14^{\circ} 32^{\prime} 19.0^{\prime \prime} \mathrm{N}, 60^{\circ} 53^{\prime} 49.2^{\prime \prime} \mathrm{W}$ \\
\hline Galion & Trinité & Soil with alluvia / ferrisols & 10 & $14^{\circ} 43^{\prime} 10.9^{\prime \prime} \mathrm{N}, 60^{\circ} 57^{\prime} 39.7^{\prime \prime} \mathrm{W}$ \\
\hline Escouët & Rivière-Pilote & Ferrisols & 61 & $14^{\circ} 29^{\prime} 52.6^{\prime \prime} \mathrm{N}, 60^{\circ} 53^{\prime} 22.1^{\prime \prime} \mathrm{W}$ \\
\hline Lézarde & Saint-Joseph & Brown soil rusts with halloysite & 35 & $14^{\circ} 39^{\prime} 38.6^{\prime \prime} \mathrm{N}, 60^{\circ} 59^{\prime} 47.8^{\prime \prime} \mathrm{W}$ \\
\hline Pavé 11 & Saint-Joseph & Brown soil rusts with halloysite & 36.5 & $14^{\circ} 39^{\prime} 31.4^{\prime \prime} \mathrm{N}, 60^{\circ} 59^{\prime} 52.1^{\prime \prime} \mathrm{W}$ \\
\hline Sonson & Saint-Esprit & Ferrisols & 152 & $14^{\circ} 32^{\prime} 49.9^{\prime \prime} \mathrm{N}, 60^{\circ} 55^{\prime} 11.7^{\prime \prime} \mathrm{W}$ \\
\hline Ti Jacques & Rivière-Pilote & Ferrisols & 67 & $14^{\circ} 29^{\prime} 55.3^{\prime \prime} \mathrm{N}, 60^{\circ} 53^{\prime} 19.2^{\prime \prime} \mathrm{W}$ \\
\hline
\end{tabular}

Table II.

Identifying information of the fruits of various accessions of Mammea americana, collected during a survey done in 2005 on Martinique Island (France).

\begin{tabular}{|c|c|c|c|c|c|c|}
\hline Epicarp appearance & $\begin{array}{l}\text { Average fruit weight } \\
\text { (g) }\end{array}$ & Pulp color & $\begin{array}{c}\text { Seed } \\
\text { number }\end{array}$ & $\begin{array}{l}\text { Pulp adherence } \\
\text { to seed }\end{array}$ & $\begin{array}{l}\text { Sugar } \\
\text { content }\end{array}$ & $\mathrm{FI}$ \\
\hline $\begin{array}{l}\text { Low or strong verrucosity } \\
\text { Clear or dark brown }\end{array}$ & $\begin{array}{c}\text { Small: }<400 \\
\text { Medium: }>400 \text { and }<600 \\
\text { Large: }>600\end{array}$ & $\begin{array}{c}\text { Yellow, } \\
\text { yellow-orange } \\
\text { or orange }\end{array}$ & 1 to 3 & $\begin{array}{l}\text { Null, partial } \\
\text { or strong }\end{array}$ & $\begin{array}{l}\text { Low, } \\
\text { medium or } \\
\text { high }\end{array}$ & $\begin{array}{l}\text { From little } \\
\text { flavor to very } \\
\text { aromatic }\end{array}$ \\
\hline
\end{tabular}

On Martinique Island, the diversity of quality of the M. americana fruits was noted; however, the part played by the environmental and genetic components in the phenotypical expression has not yet been analyzed. Beginning with a thorough characterization of the species diversity, our study thus attempted to analyze the variability of certain quality parameters of fruits collected in Martinique on well-identified trees and to indicate tendencies which would make it possible to explain, at least partly, the origin of this variability.

\section{Materials and methods}

A selection of interesting mamey trees with fruits of good quality was made during a first survey carried out in the whole of Marti- nique, during the principal crop period of M. americana, in 2005. This step was facilitated by information given by certain private individuals or professional inhabitants of Martinique. It led to the selection of 10 trees which were precisely located by their geographical coordinates (table I). A nonexhaustive list of the fruit characters observed during this survey was drawn up (table II).

During the 2006 picking, a finer phenotypical analysis was carried out for the production of each selected individual, when that was possible. It related to biometric fruit characteristics and biochemical pulp analyses. The consumption of mamey being done traditionally starting with fallen fruits, it is those which were collected at the bottom of the trees to be analyzed in the laboratory. 
The biometric characteristics concerned: - weight of fruit $\left(\mathrm{W}_{\text {fruit }}\right)$, seeds $\left(\mathrm{W}_{\text {seed }}\right)$ and epicarp $\left(\mathrm{W}_{\text {epicarp }}\right)$ (digital scale, precision $0.10 \mathrm{~g}$ ),

- height of fruit measured using a slide caliper (precision $0.02 \mathrm{~mm}$ ),

- circumference of fruit determined with a meter ribbon (precision $1 \mathrm{~mm}$ ).

The weight of pulp $\left(\mathrm{W}_{\text {pulp }}\right)$ was established according to the relation: $\mathrm{W}_{\text {pulp }}=$ $\left[\mathrm{W}_{\text {fruit }}-\left(\mathrm{W}_{\text {epicarp }}+\mathrm{W}_{\text {seed }}\right)\right]$. Consequently, the percentage of pulp (P\%) was obtained by the relation: $\mathrm{P} \%=\left(\mathrm{W}_{\text {pulp }} / \mathrm{W}_{\text {fruit }}\right) \times 100$.

The biochemical characteristics were measured using $50 \mathrm{~g}$ of fresh pulp crushed with $50 \mathrm{~mL}$ of distilled water. The puree obtained was then centrifuged for $10 \mathrm{~min}$ with 6000 turns $\cdot \min ^{-1}$ at $4{ }^{\circ} \mathrm{C}$. The supernatant was used to analyze the total soluble solids and the total titrable acidity. The total soluble solids, expressed in ${ }^{\circ}$ Brix, were measured using a digital refractometer with temperature compensation (ATAGO, model Palette PR_32); the total titratable acidity, expressed in $\mathrm{mEq} \cdot 100 \mathrm{~mL}^{-1}$ of juice, was measured using a motorized burette, by acidimetric titration of $10 \mathrm{~mL}$ of supernatant by $0.1 \mathrm{~N}$ soda $(\mathrm{NaOH})$, in the presence of phenolphthalein.

Only eight trees among the ten selected individuals were used for the analysis of the biometric fruit characteristics, owing to the fact that two of the selected trees were cut back at the end of 2005 and their 2006 production was thus lost. In total, these analyses related to 91 fruits. The study of the biochemical pulp characteristics related only to the fruits of seven individuals, 58 fruits in total.

Measurements of fruits collected in 2006 at the bottom of the ten selected $M$. americana individuals were exploited using a crossed board, based on the criteria of mamey characterization, as previously drawn up (table II). Each characteristic considered received a qualitative score, in function of the importance given to the criterion concerned by the surveyed population (private individuals or fruit-processing professionals): from 0 (worst score) to 8 (best score) for characteristics considered to be important (adherence of pulp to seeds, fla- vor and sugar content), from 1 to 5 for interesting but less required characters (color of pulp, seed number and average fruit weight) and from 0 to 3 for the epicarp aspect, considered to be additional. The final score obtained for each tree made it possible to establish a first qualitative classification of the ten identified individuals.

The data on total soluble solids (TSS) and titrable acidity (TA) measurements, subjected to statistical tests, were studied by variance analyses according to a model on only one factor (the selected tree) and five levels (five tree localizations: Charité, Escouët, Lézarde, Pavé 11 and Ti Jacques). To highlight a potential soil effect, a principal component analysis was carried out on the basis of five biometric parameters (weight, height, fruit circumference, pulp percentage in the fruit and seed weight) and two biochemical parameters (TSS and TA). These statistical analyses were carried out with the software Minitab Software Release 13.20, year 2000. Individuals with a number of too-weak measurements, the case of the Choisy and Sonson trees, were not taken into account.

\section{Results}

\subsection{Biometric characteristics of the ripe fruits}

The analysis of the biochemical characteristics measured on ripe fruits of $M$. americana revealed a great variability in weight between the fruits of the same tree (table III). Thus, for example, the Charité tree, whose fruit weight presented the weakest standard deviation [average weight of $(552 \pm 80) \mathrm{g}$ ], presented fruits with a range of weights from (443 to 685) g. A great variability in weight could also be observed between the fruits of the various locations. The average weight varied from (335 \pm 101) $\mathrm{g}$ (Choisy accession) to $(858 \pm 407) \mathrm{g}$ (Coco accession) (table III). This variability was also observed for the fruits picked at the bottom of trees of the same location [Escouët $(547 \pm 150) \mathrm{g}$ and Ti Jacques (696 \pm 185) g accessions, for example]. The average weight measured on all the fruits collected at the bottom of the various trees was 


\begin{tabular}{|c|c|c|c|c|c|c|c|}
\hline Accession & $\begin{array}{l}\text { Average fruit } \\
\text { weight } \\
\text { (g) }\end{array}$ & $\begin{array}{l}\text { Average fruit } \\
\text { height } \\
\text { (cm) }\end{array}$ & $\begin{array}{l}\text { Average fruit } \\
\text { circumference } \\
\text { (cm) }\end{array}$ & $\begin{array}{c}\text { Average seed } \\
\text { number }\end{array}$ & $\begin{array}{c}\text { Average seed } \\
\text { weight } \\
\text { (g) }\end{array}$ & $\begin{array}{l}\text { Percentage } \\
\text { of pulp } \\
(\%)\end{array}$ & $\begin{array}{l}\text { Seed } \\
\text { adherence } \\
\text { to pulp }\end{array}$ \\
\hline Charité & $552( \pm 80)$ & $10.8( \pm 0.7)$ & $31.6( \pm 1.6)$ & $1.0( \pm 0.0)$ & $75( \pm 12)$ & $74( \pm 2.7)$ & No \\
\hline Choisy & $335( \pm 101)$ & $8.7( \pm 0.6)$ & $26.9( \pm 3.3)$ & $1.1( \pm 0.3)$ & $68( \pm 16)$ & $60( \pm 7.3)$ & Yes \\
\hline Coco & $858( \pm 407)$ & $11.6( \pm 1.5)$ & $38.1( \pm 6.9)$ & $1.6( \pm 0.9)$ & $80( \pm 23)$ & $74( \pm 8.2)$ & No \\
\hline Escouët & $547( \pm 150)$ & $9.7( \pm 0.6)$ & $31.5( \pm 2.9)$ & $1.1( \pm 0.3)$ & $103( \pm 24)$ & $65( \pm 8.1)$ & Yes \\
\hline Lézarde & $640( \pm 259)$ & $10.6( \pm 1.2)$ & $33.2( \pm 5.0)$ & $1.4( \pm 0.7)$ & $68( \pm 37)$ & $68( \pm 9.0)$ & Partial \\
\hline Pavé 11 & $670( \pm 217)$ & $10.0( \pm 1.1)$ & $35.7( \pm 4.3)$ & $1.3( \pm 0.6)$ & $58( \pm 14)$ & $69( \pm 5.8)$ & Yes \\
\hline Sonson & $451( \pm 89)$ & $9.3( \pm 0.8)$ & $30.8( \pm 2.0)$ & $1.0( \pm 0.0)$ & $48( \pm 8)$ & $65( \pm 5.5)$ & No \\
\hline Ti Jacques & $696( \pm 185)$ & $11.5( \pm 0.8)$ & $35.9( \pm 4.4)$ & $1.5( \pm 0.6)$ & $59( \pm 6)$ & $79( \pm 4.4)$ & No \\
\hline
\end{tabular}

$(594 \pm 160) \mathrm{g}$, and the range of the fruit weights observed went from $222 \mathrm{~g}$ to $1350 \mathrm{~g}$, which is lower than the values mentioned by Campbell [1] and Francis [5].

The great fruit weight variability highlighted within the same accession and between different accessions can be correlated with the great variability in the corresponding sizes (fruit circumference and height) (table III). The average circumference of all the accessions was (33.0 \pm $3.5) \mathrm{cm}$ and the average height was (10.3 \pm 1.0) $\mathrm{cm}$, which is higher than the results of Mourao and Beltrati in Brazil [14].

In the majority of cases, the fruits of the various prospected trees presented only one seed; more rarely, two or three seeds could be found in the same fruit. Only the Coco, Lézarde, Pavé 11 and Ti Jacques accessions presented fruits with three seeds (20\% of the fruits observed for the Coco accession and 10\% for Lézarde, Pavé 11 and Ti Jacques) (table III). The average seed number for all accessions was $(1.3 \pm 0.2)$, which is also lower than the data mentioned by Mourao and Beltrati from Brazil [14] and by Francis from Puerto Rico [5].

The seed weight had a significant variability within the fruits of the same tree: (48 to 69) $\mathrm{g}$ for Ti Jacques, the accession presenting the weakest standard deviation, and between the fruits of different trees: from $(48 \pm 8) \mathrm{g}$ for the Sonson accession to $(103 \pm$
24) $\mathrm{g}$ for the Escouët accession (table III). This great variability was also noted between the fruits collected at the bottom of trees located in the same land: Ti Jacques with $(59 \pm 6) \mathrm{g}$ and Escouët with (103 \pm 24) g, for example. The average seed weight of the fruits was $(69 \pm 17) \mathrm{g}$, a result similar to the data reported by Campbell [1] and Francis [5]. The presence of several seeds in the same fruit did not have an influence on the individual average seed weight.

The pulp percentages of the fruits were heterogeneous between the fruits of different accessions (table III): they went from $(60 \pm 7.3) \%$ for the fruits of the Choisy accession to $(79 \pm 4.4) \%$ for the Ti Jacques fruits. However, this parameter appeared relatively stable within the production of the same tree. The average pulp percentage observed of the fruits of the surveyed individuals was $(69 \pm 6) \%$.

Lastly, from a qualitative point of view, the analyzed fruits had a strong heterogeneity between accessions for the character of pulp adherence to seed (table III). For the Belleville, Charité, Coco, Galion, Sonson (figure 1) and Ti Jacques (figure 2) accessions, pulp proved not to adhere at all to seeds, whereas, for the Lézarde accession, the fruit pulp adhered partially to seeds, primarily on the level of the junction between the cotyledons. The accessions Choisy, Escouët and Pavé 11 (figure 3) presented fruits with a completely adherent pulp. 


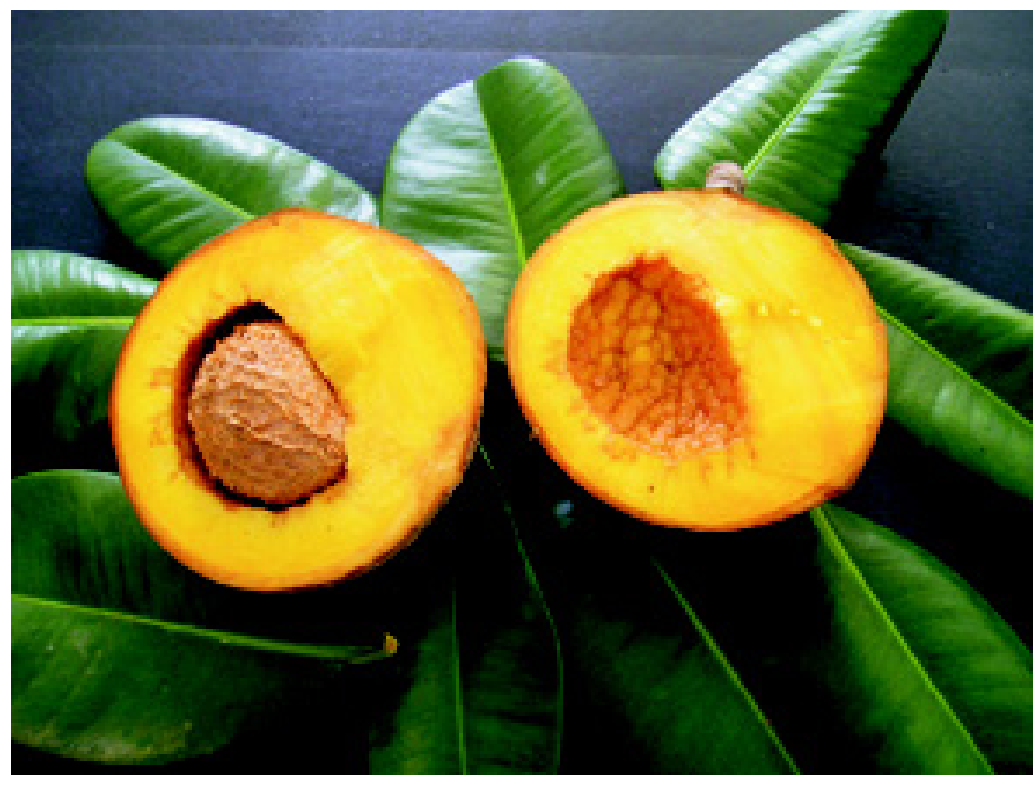

Figure 1.

Open fruit of the Sonson variety (mamey, Mammea americana

L.) selected on Martinique Island (France).

\section{Figure 2.}

Whole fruit and cut fruit of the Ti Jacques variety (mamey, Mammea americana L.) selected on Martinique Island (France).

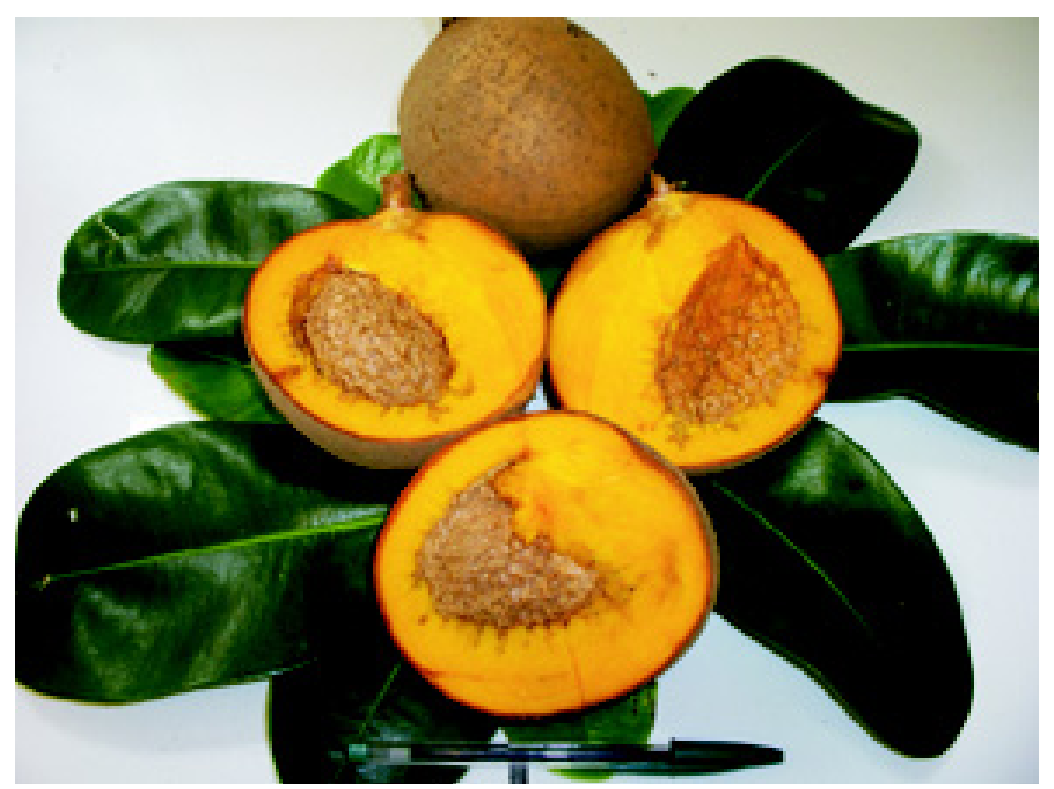

(table IV), which are higher than the (9 to 13.1) ${ }^{\circ}$ Brix found for the fruits of Venezuelan accessions by Manzano Mendez and Dris [11]. Moreover, variability within the same accession was relatively restricted (weak standard deviations), like that measured between fruits picked at the bottom of trees located in the same land: the $\mathrm{Ti}$ Jacques (15.6 ${ }^{\circ}$ Brix) and Escouët (16.9 ${ }^{\circ}$ Brix) accessions, and Lézarde (11.7 ${ }^{\circ}$ Brix) and Pavé 11 (11.9 ${ }^{\circ}$ Brix) accessions (table $\left.I V\right)$.

Values of total titrable acidity were also significantly very variable according to the fruits of the various accessions $(p<0.001)$. Ti Jacques fruits with $7.7 \mathrm{mEq} \cdot 100 \mathrm{~mL}^{-1}$ of juice and Escouët with $8.5 \mathrm{mEq} \cdot 100 \mathrm{~mL}^{-1}$ of juice presented the highest values, whereas the pulp of Pavé 11 , with $4.4 \mathrm{mEq} \cdot 100 \mathrm{~mL}^{-1}$ of juice, had the lowest acidity. The values measured went from ( 4.3 to 8.5$) \mathrm{mEq} \cdot 100 \mathrm{~mL}^{-1}$ of juice (table IV).

The relationship between the soluble solids and the total titrable acidity, measured in the pulp of the sampled fruits, varied according to the accession. It oscillated from 2.0 to 2.7 (table IV). The accessions with fruits with high soluble solids generally presented the highest contents of total titrable acidity.

\subsection{Hierarchical classification of the selected accessions}

The qualitative classification of the ten selected accessions, obtained by realization of a cross board (table $V$ ) based on the criteria of characterization for mameys (table II), showed that five of the ten studied trees were dissociated with a maximum score close to 40 (Sonson, Charité, Belleville, Galion and Ti Jacques). These five accessions thus have the characters most appreciated by the consumers and the industrialists: nonadherence of seeds to pulp, high sugar and flavor contents, low seed number and high average fruit weight.

\subsection{Effect of the land on the variability of the fruit characteristics}

The principal component analysis based on the majority of the biometric (average weight, height and circumference of the fruits, average seed weight and pulp percentage) and 
biochemical characteristics measured on the collected fruits made it possible to highlight two main axes explaining $67 \%$ of total variability (figure 4 ). Axis 1 ( $45 \%$ of total variability) differentiates the accessions according to the biometric characteristics, whereas axis 2 ( $22 \%$ of total variability) differentiates the trees according to the biochemical characteristics (TSS and TA) (figure 5). The Lézarde and Pavé 11 accessions had a great variability in weight, size and pulp percentage. On the contrary, the Escouët and Ti Jacques accessions located in Rivière-Pilote (Martinique) seemed more homogeneous for these characteristics. Moreover, the Escouët and Ti Jacques accessions were clearly different in their soluble solids and total titrable acidity contents and appear significantly higher, for these characters, than the Charité, Lézarde and Pavé 11 accessions.

\section{Discussion}

The qualitative analyses of the accessions which we observed and analyzed in Martinique are close to the results obtained by Campbell [1], the only work having followed objectives similar to ours. However, it is not possible for us to compare these two studies from a quantitative point of view since the information given by Campbell is only qualitative. Some of the collected accessions (Sonson, Charité, Belleville, Galion and Ti Jacques) appeared very promising to us for a market of fresh fruit consumption: high flavor and sugar contents, nonadherence of pulp to seeds, fruit of average size, significant pulp percentage, appealing pulp color and smooth epicarp (figure O); Some of them could also be interesting for processing in small production units because of high fruit weight and size (Coco, Galion, Charité and Ti Jacques).

According to the studied characteristics, significant differences appeared within each selected accession. Intra-tree variability was lower than inter-tree variability, and even null for certain characters; this inter-tree variability can also be low between trees growing in the same land.

Certain tendencies appeared: thus, the seed adherence to pulp did not vary between the fruits of the same tree, whatever the land;

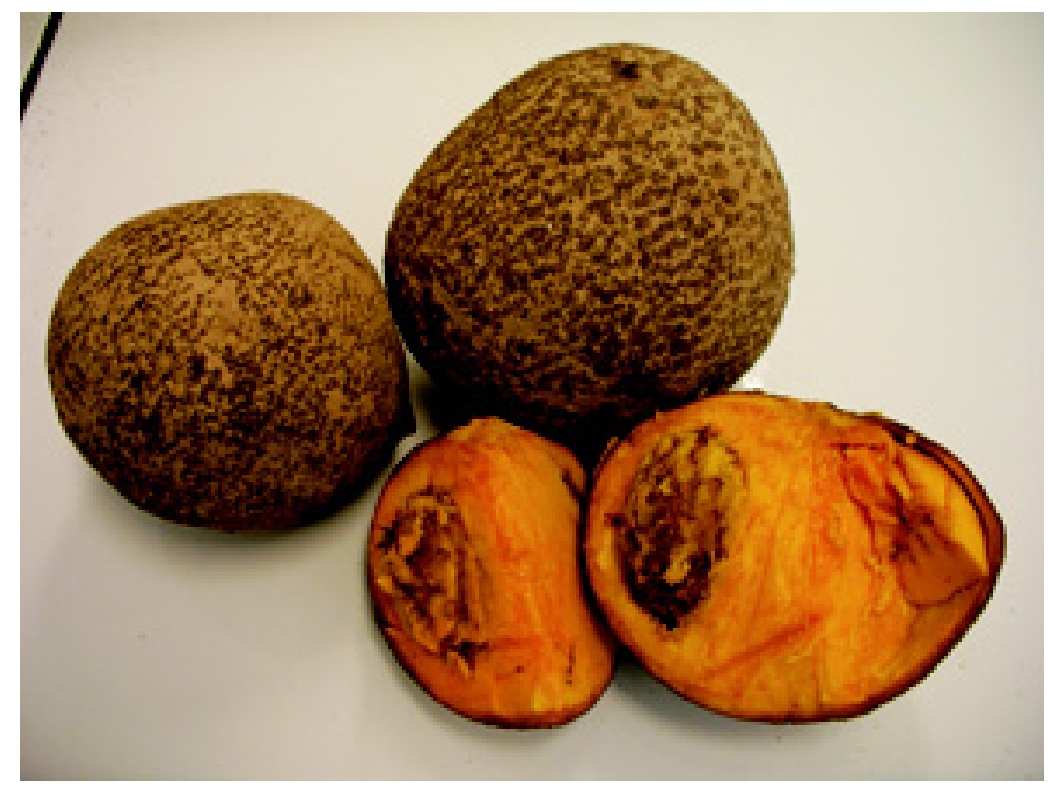

this would imply a genetic determinism of Figure 3.

this character. The accessions Ti Jacques Whole fruits and cut fruit of the (nonadherent seeds with pulp) and Escouët Pavé 11 variety (mamey, (completely adherent seeds), present in the Mammea americana L.) same land, emphasize this assumption.

The weak intra-tree variation of the total soluble solids content and total titrable acidity also deserves to be underlined; it is found between the fruits of accessions growing in the same land (Escouët and $\mathrm{Ti}$ Jacques accessions located in the commune of Rivière-Pilote and Lézarde and Pavé 11 accessions present in Saint-Joseph).

Other analyses using certain techniques of finer characterization, molecular biology for example, will have to be carried out to selected on Martinique Island (France).

\section{Table IV.}

Biochemical characteristics of the pulp of fruits picked in 2006 on seven individuals of Mammea americana, selected after a survey carried out in 2005 on Martinique Island (France).

\begin{tabular}{lccc} 
Accession & Total soluble solids & Total titrable acidity & {$[$ TSS / TA] } \\
\hline Charité & $12.7( \pm 0.6) \mathrm{b}$ & $4.9( \pm 1.2) \mathrm{bc}$ & $2.6( \pm 0.6)$ \\
Choisy & $10.3( \pm 0.1)$ & $4.9( \pm 1.2)$ & $2.1( \pm 0.6)$ \\
Escouët & $16.9( \pm 1.6) \mathrm{a}$ & $8.5( \pm 1.5) \mathrm{a}$ & $2.0( \pm 0.3)$ \\
Lézarde & $11.7( \pm 1.7) \mathrm{b}$ & $6.4( \pm 3.6) \mathrm{abc}$ & $2.2( \pm 1.0)$ \\
Pavé 11 & $11.9( \pm 1.6) \mathrm{b}$ & $4.4( \pm 1.0) \mathrm{c}$ & $2.7( \pm 0.7)$ \\
Sonson & $14.3( \pm 0.3)$ & $7.1( \pm 0.3)$ & $2.0( \pm 0.1)$ \\
Ti Jacques & $15.6( \pm 2.5) \mathrm{a}$ & $7.7( \pm 1.9) \mathrm{ab}$ & $2.1( \pm 0.5)$
\end{tabular}




\section{Table V.}

Dynamic cross board allowing the accession classification of Mammea americana, according to the quality of the fruits collected on Martinique Island (France) during the season of production in 2006. Scores obtained for each criterion of fruit characterization: from 0 (worst score) to 8 (best score) for characteristics considered to be important (pulp adherence to seeds, flavor and sugar content), from 1 to 5 for interesting but less required characters (color of pulp, seed number and average fruit weight), and from 0 to 3 for the epicarp aspect, considered to be additional.

\begin{tabular}{lccccccccccc} 
Criteria & Sonson & Charité & Belleville & Galion & Ti Jacques & Coco & Choisy & Escouët & Lézarde & Pavé 11 & Total \\
\hline Pulp adherence to seeds & 8 & 8 & 8 & 8 & 8 & 8 & 0 & 0 & 4 & 0 & 52 \\
Flavor & 8 & 8 & 8 & 8 & 8 & 8 & 8 & 8 & 8 & 8 & 80 \\
Epicarp appearence & 2 & 2 & 3 & 3 & 3 & 1 & 3 & 0 & 2 & 1 & 20 \\
Color of pulp & 3 & 3 & 3 & 3 & 5 & 1 & 3 & 3 & 3 & 3 & 30 \\
Seed number & 7 & 7 & 5 & 5 & 3 & 3 & 5 & 5 & 3 & 3 & 46 \\
Average fruit weight & 5 & 5 & 5 & 4 & 4 & 4 & 1 & 5 & 4 & 4 & 41 \\
Sugar content & 8 & 8 & 8 & 8 & 8 & 8 & 0 & 8 & 4 & 4 & 64 \\
Total & 41 & 41 & 40 & 39 & 39 & 33 & 20 & 29 & 28 & 23 & 333
\end{tabular}

\section{Figure 4.}

Axes 1 and 2 of a principal component analysis carried out on biometric and biochemical characteristics of fruits of Mammea americana L. (mamey), collected in 2006 at the bottom of selected trees on Martinique Island (France).

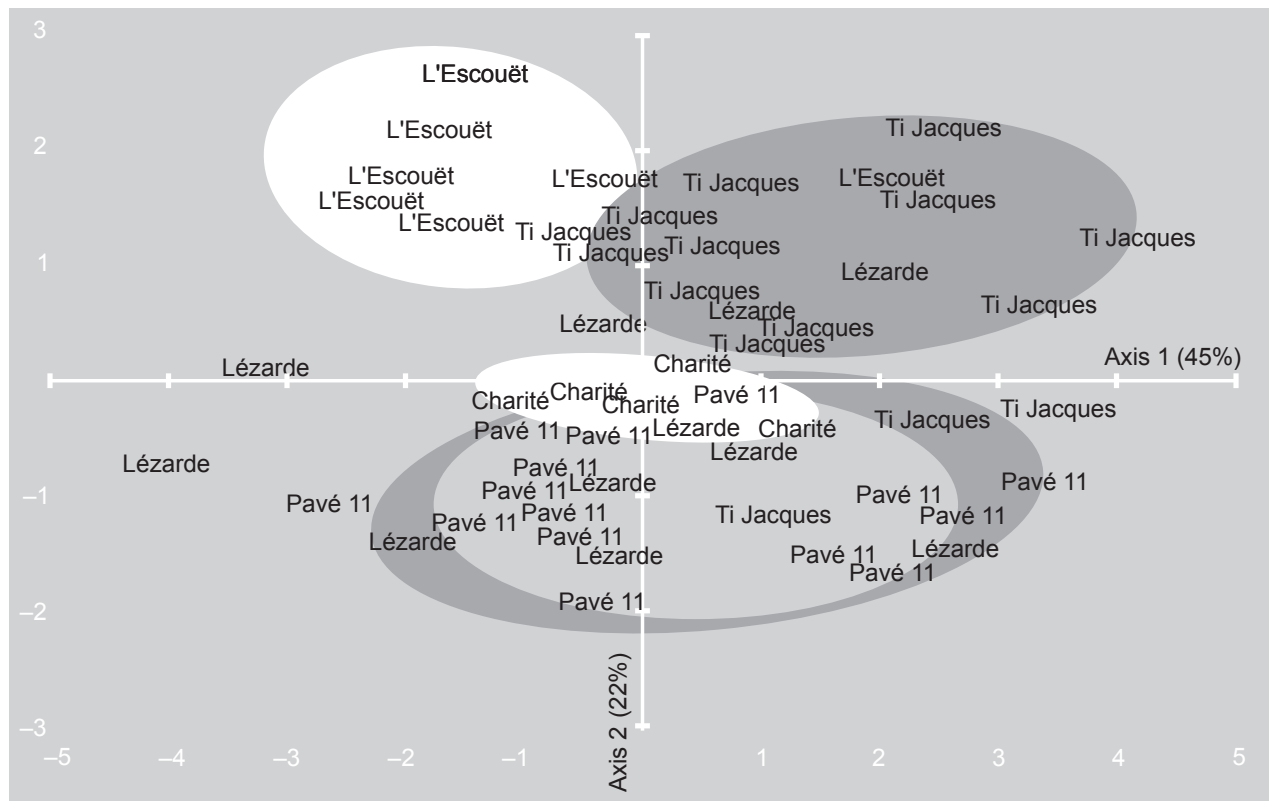

check these tendencies, while taking into account all parameters which might influence the phenotypes observed (age of the individual, alternation with the passing of years, etc.).

Contrary to the preceding characters, the average fruit weights and sizes, seed numbers and weights and pulp percentages measured do not seem related to an accession, or even a land. However, the Escouët and $\mathrm{Ti}$ Jacques accessions had relatively homogeneous fruit weights and sizes, and the fruits of the Charite and Sonson accessions produced only one seed. A more significant fruit sampling will have to be carried out within each accession to check the origin of the variability of these parameters.

\section{Conclusion}

Our study regarding certain mamea trees of the Antilles selected in the field in Martinique carried out the first characterization of the phenotypical diversity of $M$. americana 
present on the island. Fruits of this tree are well known and are very largely appreciated by the local population. The traditional multiplication by sowing maintains a significant genetic diversity which results in a broad heterogeneity of phenotypes.

The biometric and biochemical characteristics (fruit size, seed number and weight, pulp percentage, pulp adherence to seed, soluble solids content and total titrable acidity) often appeared higher than those reported before in the literature, because of our protocol of collection based on a targeted survey. However, our research took into account only certain fruit quality standards; they will have to be supplemented by taking into account agronomic criteria: tree yields, precocity of production, tree tolerance or resistance to various fungi and pests, etc.

The phenotypical characterization of the various individuals observed in 2005 made it possible to constitute a collection of $M$. americana from vegetative multiplication by grafting of the selected genotypes; an experimental plot was thus set up from which it will be possible to undertake a finer agronomic and sensory evaluation: behavior of the seedlings grafted in the experimental plot, yield of the clones, sensitivity to pests or diseases, pomological fruit characteristics in identical agro-ecological conditions and organoleptic characteristics.

The preliminary study that we carried out was thus thorough in order to lead, in the long term, to the diffusion of selected varieties of $M$. americana. The results obtained made it possible to draw up certain tendencies for the role of the environmental and genetic components for the expression of the phenotypes observed. A genetic study based on the use of judicious molecular markers could help to more precisely determine the role of these components. In so far as the variability highlighted has a genetic base, it could be used, later on, within an improvement program based on targeted hybridizations.

\section{Acknowledgements}

The authors thank the enthusiastic people, the experts, private individuals and farmers who gave them free access to their trees, answered their questions, allowed them to

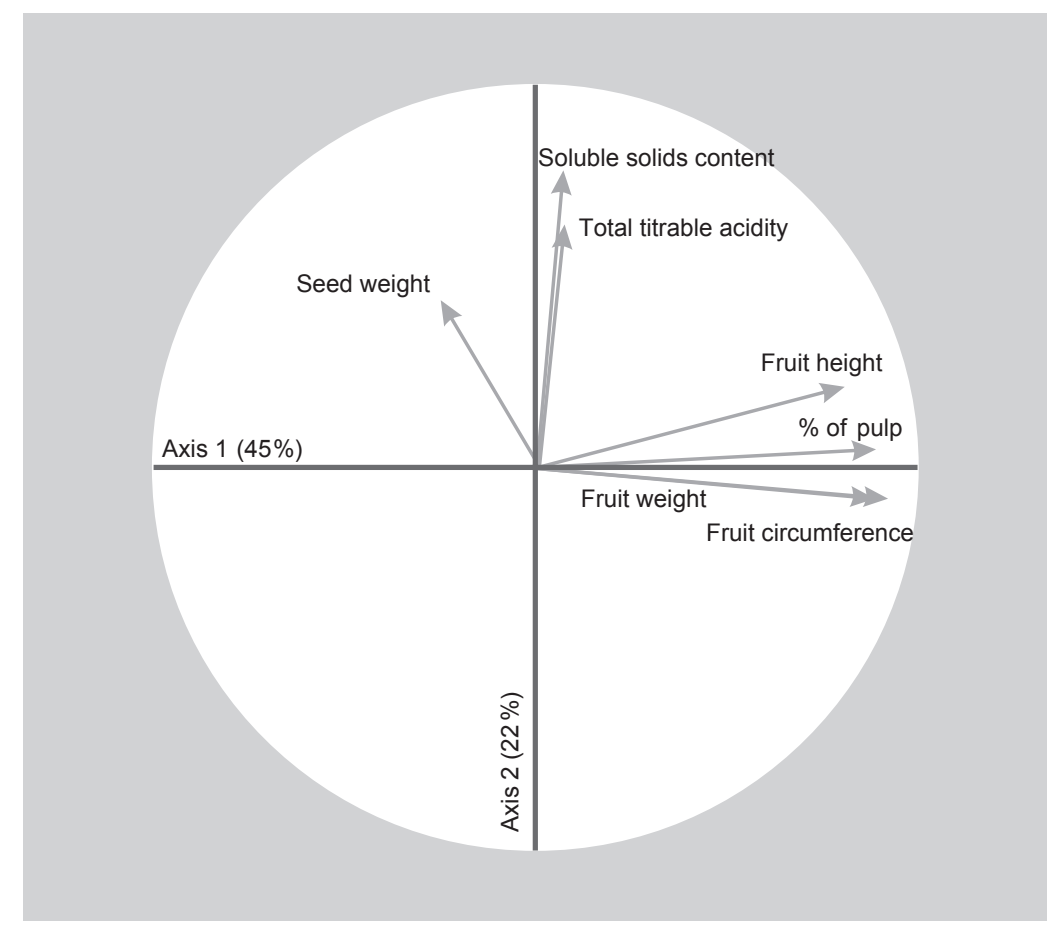

Figure 5.

Correlation circle obtained from a principal component analysis carried out on biometric and biochemical characteristics of fruits of Mammea americana L. (mamey), collected in 2006 at the bottom of selected trees on Martinique Island (France).

Figure 6.

Ripe fruits of the Ti Jacques variety (mamey, Mammea americana L.) selected on Martinique Island (France): fruits 1 to 6 with attractive color and smooth epicarp more appreciated for fresh fruit consumption than fruits 1 and 2, brown, with rough epicarp.

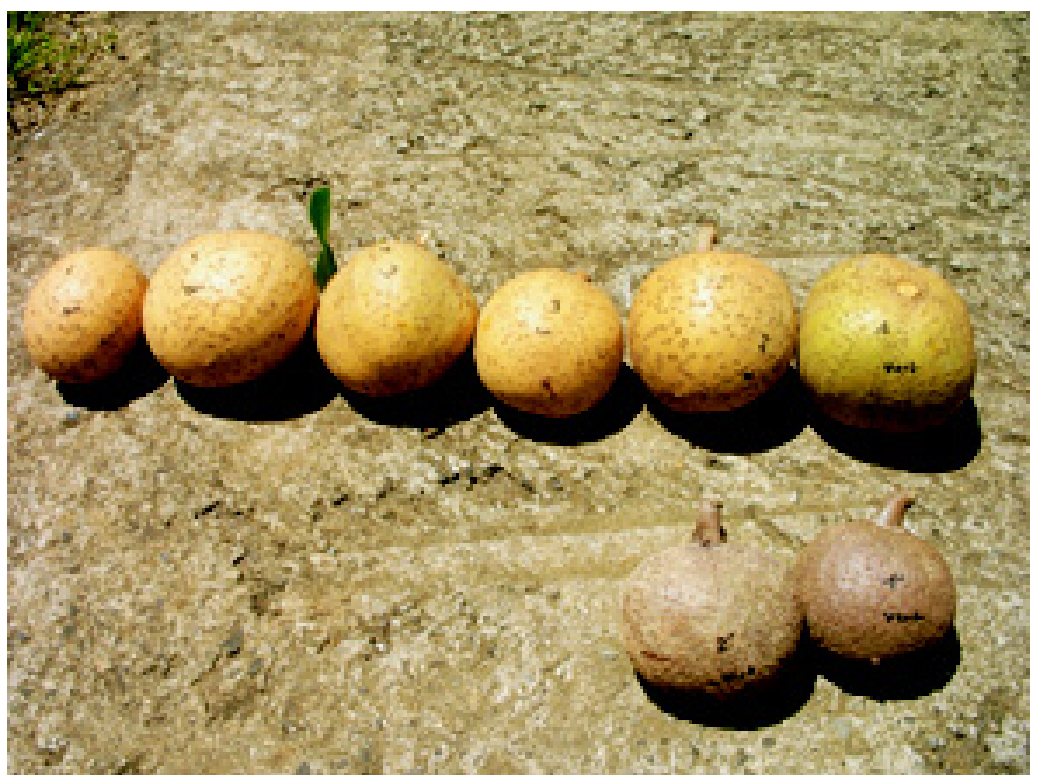


take away plant material, fruits and grafts, and directed them towards other contacts. They also thank C. Bugaud for his assistance with the statistical analyses and M. Jannoyer for her advice.

\section{References}

[1] Campbell R.J., Collecting Mammea americana L. in tropical America: potential for Florida, Proc. Fla. State Hortic. Soc. 118 (2005) 242-243.

[2] De Candole A., Origine des plantes cultivées, Libr. Germer Baillière et Cie., Paris, France, 1883, rééd. fac-similé : Laffite, Marseille, France, 1984.

[3] Morton J.F., Fruits of warm climates, Curtis F., Dowling Jr. (Eds.), Miami, 1987, 304-307.

[4] Labat J.B., Nouveau voyage aux isles de l'Amérique, Délespine éd., Paris, France, 1694, pp. 179-180.

[5] Francis J.K., Mammea americana L., mamey, mammee apple, USDA, For. Serv., South. For. Exp. Stn., Rio Piedras, Puerto Rico, 1989, 4 p.

[6] Zamore R., Ebroïn A., Vertus et secrets des plantes médicinales des Antilles, Edouard Kolodziej éd., III, Fort-de-France, Martinique, 1984, p.13.
[7] Poupon J., Chauvin G., Les arbres de la Martinique, Off. Natl. For., Guadeloupe, 1983, 210-211.

[8] Dunthorn M., Cryptic dioecy in Mammea (Clusiaceae), Plant Syst. Evol. 249 (2004) 191-196.

[9] Kervégant D., Les plantes utiles et ornementales de la Martinique, Fascicule II, Impr. Gouv., Fort de France, Martinique, 1937, 95-96.

[10] Akamine E.K., Goo T., Respiration and ethylene production in Mammee apple (Mammea americana L.), J. Am. Soc. Hortic. Sci. 103 (1978) 308-310.

[11] Manzano Mendez J.E., Dris R., Effect of storage atmosphere and temperature on soluble solids in mamey amarillo (Mammea americana L.) fruits, in: Ben-Arie R., PhilosophHadas S. (Eds.), Proc. 4th Int. Conf. Postharvest, Acta Hortic. 553 (2001) 675-676.

[12] Morean F., L'abricot de Saint-Domingue. Un fruit sous exploité à Trinidad et Tobago, Fruits 46 (6) (1991) 699-702.

[13] Colmet-Daage M.F., Carte des sols à 1/20 000 de la Martinique, Orstom, Fort-de-France, France, 1970, 24 feuilles $26 \mathrm{~cm} \times 70 \mathrm{~cm}$.

[14] Mourao K.S.M., Beltrati C.M., Morphology and anatomy of developing fruits and seeds of Mammea americana L. (Clusiaceae), Rev. Bras. Biol. 60 (4) (2000) 701-711.

\section{El mamey (Mammea americana L.) en Martinica: un patrimonio para ser valorizados.}

Resumen - Introducción. El mamey (Mammea americana L., de la familia Clusiaceae) ya estaba presente antes de la colonización española. Su área de reparto engloba la parte tropical de América y la zona del Caribe. Se observa en la isla una diversidad fenotípica considerable, con frutos de calidad muy diferente y con características agronómicas, pomológicas y bioquímicas también muy diferenciadas. Nuestro estudio se basó en la identificación de individuos con una reputación mejor, así como en la caracterización fenotípica de sus frutos. Material y métodos. Una prospección realizada entre abril y septiembre de 2005 permitió la cosecha de frutos de 10 árboles, de los cuales la población juzgó que ofrecían una producción de buena calidad, es decir: presencia de pepitas poco abundantes y no adherentes a la pulpa en los frutos, así como un sabor azucarado y un aroma pronunciado de la pulpa. A lo largo del periodo de producción de 2006 se realizaron unos análisis biométricos y bioquímicos complementarios (extracto seco soluble y acidez libre total) en los frutos y en el momento de la cosecha. Resultados y discusión. Las características biométricas y bioquímicas medidas en el momento de nuestros análisis fueron casi siempre superiores a aquellas citadas en la bibliografía. Ciertas muestras de material procedente de Martinica se distinguieron entre ellas. Además presentan unas bazas importantes tanto para su difusión en tanto que materia fresca como para una transformación de calidad. Por otro lado, ciertas tendencias se ponen de manifiesto en relación a la variabilidad observada de ciertos caracteres. De este modo, la variabilidad de las características bioquímicas medidas en el seno de una misma muestra de material y en muestras de material de un mismo territorio es escasa. Es nula en cuanto a la adherencia de las pepitas en la pulpa de los frutos pertenecientes a una misma muestra de material. Conclusión y perspectivas. El estudio presentado es uno de los primeros sobre la identificación y la caracterización de la diversidad fenotípica presente en la especie $M$. americana L. en general; y, más particularmente, en la isla de Martinica. Los resultados obtenidos son alentadores para el desarrollo de una filial de diversificación. Ciertas tendencias puestas en evidencia dan lugar a nuevas perspectivas de investigaciones en relación con papel que ocupan ciertos componentes medioambientales y genéticos en el rendimiento de los fenotipos observados.

Caribe / Martinica / Mammea americana / frutas / variación genética / diversificación / criterios de selección 